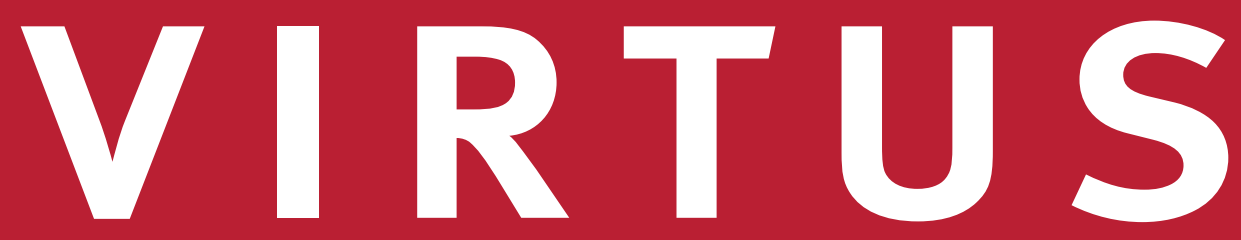

$27 \mid 2020$




Laura Smeets

\section{Een kroon voor het Koninkrijk}

Het Huis Oranje-Nassau kent een lange traditie van macht, al sinds het stadhouderschap van Willem van Oranje in het midden van de zestiende eeuw. De machtspositie van de familie was niet altijd even sterk en het stadhouderschap werd zelfs meerdere keren 'voor eeuwig' afgeschaft. Toch wist de familie elke keer weer terug te komen en verwierf zij met name tegen het einde van de achttiende eeuw een haast monarchale status. Dit en meer stuitte de van bestuursmacht uitgesloten burgers tegen de borst en zo ontstond er een door de patriotten geleide revolutie. Deze revolutie werd korte tijd later voltooid door de Fransen, die in 1794 Nederland binnentrokken. Dit noopte de stadhouderlijke familie in $\mathbf{1 7 9 5}$ het land vanaf het strand van Scheveningen te verlaten. Onder Franse overheersing werd de Republiek een eenheidsstaat: de Bataafse republiek en vervolgens - van 1806 tot 1810 - een koninkrijk, met aan het hoofd Lodewijk Napoleon. In 1810 werd het land ingelijfd bij het Franse keizerrijk.

De burgers die de omwenteling in gang hadden gezet en de Fransen enthousiast hadden onthaald als de voltooiers van hun revolutie voelden een steeds grotere weerzin tegen het keizerrijk. Deze breed gedragen weerzin ging gepaard met een alsmaar sterker wordend en geromantiseerd vaderlands gevoel: er waren verzetspoëten en sterk nationaal georiënteerde politici, en vaderlandse helden en historische gebeurtenissen werden weer belangrijk gevonden. ${ }^{1}$ Met deze toenemende historische interesse in het eigen land kwam ook langzaam de familie van Oranje-Nassau weer in 




Aankomst van Willem I op Scheveningen op 30 november 1813 (olieverf op paneel, Cornelis van Cuylenburg II, tussen 1813-1828; coll. Koninklijke Verzamelingen, Den Haag)

beeld. Deze was immers lange tijd onderdeel geweest van de vaderlandse geschiedenis en werd ook zo gezien: als geschiedenis. De gevoelens van zo'n twintig jaar daarvoor telden niet meer. Dit alles wordt bijvoorbeeld mooi geïllustreerd aan de hand van de inrichting van de historische zalen van de Nationale Konst-gallerij: waar men in 1800 niet verder wilde gaan dan het tentoonstellen van Oranje-objecten tot aan de zeventiende eeuw, plaatste men, zonder enig protest, in 1806 de portretten van Willem IV en Willem V. ${ }^{2}$

Ondertussen was het Franse rijk enorm gegroeid en omvatte het vrijwel heel Europa, maar Napoleons expansiedrift deed hem uiteindelijk de das om. Na de val van Napoleon voerde een driemanschap onder aanvoering van oud-regent Gijsbert Karel van Hogendorp korte tijd het bewind over Nederland. In eerste instantie was Van Ho- 
gendorp voor een herstel van de oude situatie, met aan het hoofd een Oranje-stadhouder, maar geleidelijk ging hij steeds meer het voordeel van een monarchie inzien. Toen de tijd daar was zond hij Jacob Fagel en Hendrik de Perponcher uit naar Duitsland en Engeland om de Prins van Oranje te zoeken. Willem Frederik was op dat moment al ruim een half jaar in Engeland om zijn zaak - herstel van het Huis Oranje-Nassau als regerende dynastie in Europa - te bepleiten. Op 15 november verzuchtte hij in een brief aan zijn moeder: 'We bevinden ons hier, mijn allerliefste moeder, in een zeer onaangename positie (...). We horen niets, en dat in een tijd waarin de gebeurtenissen elkaar bliksemsnel opvolgen.'3 De vraag van Van Hogendorp slechts vijf dagen na het schrijven van deze brief kwam voor de prins uit geheel onverwachte hoek, maar sloot naadloos aan bij zijn eigen wensen en ambities. Dankzij het heersende vaderlandsgevoel en de historisering van de familie van Oranje-Nassau kon de prins zonder protest terugkeren en met een schone lei beginnen. ${ }^{4}$

En zo arriveerde Willem Frederik op 30 november, tegen vier uur 's middags op het strand van Scheveningen, vanwaar zijn vader achttien jaar eerder gevlucht was. Hoe het volk hierop zou reageren was nog niet geheel duidelijk, maar mede door de rijkelijk vloeiende gratis drank kwam het op de been en zorgde zodoende voor een feestelijke intocht. Diezelfde dag reisde Elias Canneman op verzoek van Van Hogendorp naar het van oorsprong anti-orangistische Amsterdam om daar de gemoederen te peilen. Voorzichtigheid was geboden en zo sprak Canneman over Willem I in plaats van het voor de hand liggende Willem VI, dit om aan te geven dat er sprake zou zijn van een nieuwe periode en niet van een voortzetting van het oude regime. Toen Canneman rond elf uur op de Dam aankwam, was het volk massaal op de been en werden er liederen gezongen, waaronder: 'Leve Willem de Eerste onze Soeverein, de prins moet Koning van Holland zijn'.

Men liet er geen gras over groeien en riep de Prins van Oranje op 1 december uit tot Soeverein Vorst van de Verenigde Nederlanden. De inhuldiging van Willem I tot soeverein vorst van Nederland en de eed op de nieuwe grondwet vonden plaats op 29 maart 1814 in de Nieuwe Kerk in Amsterdam. Regalia of andere ceremoniële attributen waren er nog niet. Ook na zijn inhuldiging bleef Willem I soeverein vorst. Over zijn uiteindelijke titel was op dat moment nog geen beslissing genomen.

De Europese grootmachten, Engeland, Rusland, Oostenrijk en Pruisen, bepaalden tijdens het congres van Wenen dat de Noordelijke en Zuidelijke Nederlanden voortaan als één geheel verder zouden gaan (als een 'union intime et complète') en zodoende aanvaardde Willem I, op 1 augustus 1814, ook het bestuur over de Zuidelijke Nederlanden. Tijdens ditzelfde congres werd bepaald dat Willem I, na afloop van het congres, de koningstitel mocht gaan voeren. Toen Napoleon in 1815 van Elba wist te ontsnappen, wilde de prins de afsluiting van het congres niet afwachten en besloot 
hij, op 16 maart 1815, alvast de koningstitel aan te nemen. Anton Reinhard Falck schreef hierover: 'Het laatste woord omtrent de nieuwe Monarchie was te Weenen nog niet uitgesproken, en hij zette zich dus, als 't ware, zelf de kroon op 't hoofd.'5 Tien dagen later ontving de koning het protocol dat op 23 maart door het congres van Wenen was opgesteld en waarin zijn aangenomen koningstitel werd erkend. ${ }^{6}$ Er werd een nieuwe grondwet opgesteld en deze werd ceremonieel aanvaard tijdens een inhuldigingsplechtigheid op de Koningsplaats in Brussel op 21 september 1815 .

\section{Kronen en overige regalia}

Voor deze tweede inhuldigingsceremonie werd een set regalia bijeengebracht, waaronder een vergulde beugelkroon. Al duizenden jaren dragen mensen kronen. Eerst waren het versiersels van bloemen en veren en later van steeds kostbaarder materialen. Wat begon als het versieren van het hoofd evolueerde naar het onderscheiden van bepaalde hoofden. En zo ontstonden er regels wie wel en wie vooral geen kroon dragen mocht en hoe deze er uit moest zien. Als geen ander object symboliseert een kroon de macht van haar drager. Het woord kroon komt van het Latijnse woord corona. Deze corona was een krans van bloemen of bladeren die werd opgezet bij burgers en militairen die een bijzondere daad hadden verricht. ${ }^{7}$ Het uiterlijk van de kroon zoals wij hem vooral kennen is ontwikkeld in het oude Griekenland. Hier droeg men eerst banden van textiel om het hoofd, waar metalen en stenen versiersels aan vast werden gemaakt. Gaandeweg ontwikkelde zich hieruit de diadeem en werd het gehele object uit metaal vervaardigd. Dat werd vervolgens voorzien van beugels, kruizen, globes en edelstenen. ${ }^{8}$

Vanaf de kroning van Pepijn III - in 751 - werd het kronen van een vorst gebruikelijk in West-Europa. De kroon werd dan ceremonieel geplaatst op het hoofd van een gezalfde koning en werd daarmee hét symbool van koninklijke waardigheid. Tegenwoordig is er in Europa nog maar één vorst die nog altijd een kroon draagt en ook gekroond is: de Britse Koningin Elizabeth. Nog jaarlijks draagt zij haar kroon tijdens de ceremoniële opening van het parlement. De Britse kroon onderscheidt zich niet alleen doordat hij daadwerkelijk gedragen wordt, ook is hij voorzien van zeer kostbare stenen. ${ }^{9}$ Kronen die daadwerkelijk gedragen worden - of in het verleden gedragen zijn - zijn gemaakt van kostbare materialen. Deze kronen, zoals die van de Engelse vorst, verlengen immers het hoofd van de drager, tonen daarmee zijn of haar waardigheid en plaatsen de drager symbolisch ver boven de rest. Bij kronen die niet gedragen worden gaat het vooral om de symboliek, om datgene wat een kroon uitstraalt en betekent. Bij deze kronen is het materiaal zodoende van minder groot belang.

Koch, Koning Willem I, 277.

H.T. Colenbrander, Gedenkstukken VII: de vestiging van een koninkrijk (Den Haag, 1914), 744.

R. Brus, Kronen van de wereld (Amsterdam, 1992), 7.

Brus, Kronen, 8.

Ibidem, 13. 


\begin{abstract}
Rijkswapen, tevens wapen van de Koning der Nederlanden 1815-1907 (papier, kleur met goudverf, A.G. Zurcher, 1816; Hoge Raad van Adel, Den Haag, Archief van de Hoge Raad van Adel, inv.nr. 546)
\end{abstract}



Nederland kent een vrij korte geschiedenis wat betreft het gebruik van kronen. Sinds het overlijden van stadhouder Willem I, in 1584, maakte de familie gebruik van begrafeniskronen. Deze kronen, die meegedragen werden in de rouwstoet, symboliseerden de waardigheid van de overledene, als soeverein van het vorstendom Orange. ${ }^{10}$ De eerste begrafeniskronen waren niet naar koninklijk model, maar waren open banden zonder beugels. Omdat stadhouder Willem III tevens koning van Engeland was, werd bij zijn begrafenis wel het model van een koninklijke kroon gebruikt: een verguld metalen replica van de Saint Edwardskroon. Tijdens de begrafenis van Willem IV werd eveneens een dergelijke kroon naar Engels model gebruikt, bestaande uit een band met beugels en bovenop de rijksappel.

In de heraldiek spelen kronen ook een belangrijke rol. Zij geven de positie van de degene die het wapen voert weer. $\mathrm{Al}$ in de stadhouderlijke tijd maakten ook leden van de familie van Oranje-Nassau gebruik van een kroon op hun wapens. Deze beugelkronen toonden hun positie als soevereine vorsten van Orange. ${ }^{11}$ Naast de stadhouders voerde ook de Staten-Generaal een koninklijke kroon op het wapen, als symbool voor hun soevereiniteit. Het bestuursorgaan van de Republiek van de Verenigde Nederlanden had immers dezelfde functie als de monarch daarvoor. ${ }^{12}$

Als soeverein vorst koos Willem I voor een nieuw wapen, waarin de leeuw van de Republiek werd gecombineerd met verschillende belangrijke onderdelen uit de wa-

R. Brus, De juwelen van het huis Oranje Nassau (Haarlem, 1996), 127.

E. Elzenga, De inhuldigingen van Willem I tot Beatrix (Amsterdam, 2013), 186.

H. de Vries, Wapens van de Nederlanden (Amsterdam, 1995), 16. Naast de koninklijke beugelkronen, vallen in Nederland ook de hertogs-, graven-, baronnen- en ridderkronen te onderscheiden in de wapenkunde. 
pens van de Prinsen van Oranje. Voor de situatie van 1815 werd opnieuw een wapen ontworpen, een wapen dat paste bij de nieuwe status van het Verenigd Koninkrijk der Nederlanden en dus niet teruggreep op de geschiedenis van alleen het Noordelijke gedeelte. Dit nieuwe wapen, met centraal de Nassause leeuw met in zijn poten de symbolen van de Staten Generaal en eronder het devies 'Je Maintiendrai', werd het nieuwe wapen van de koning én van het Koninkrijk. Het wapenschild werd gedekt met een koninklijke beugelkroon en ook de Nassause leeuw in het schild en de schildhoudende leeuwen werden voorzien van een koningskroon. Dit nieuwe wapen werd ook afgebeeld op de rijksstandaard, naast de kroon één van de andere regalia van het koninkrijk.

De overige regalia of rijksinsigniën die naast de kroon en rijksstandaard in 1815 werden gebruikt, waren de rijksappel, de scepter en het rijkszwaard. Tezamen symboliseren de regalia de macht en waardigheid van de koning. De rijksappel kent haar oorsprong in het oude Griekenland en symboliseert de aarde als geocentrisch middelpunt van de kosmos. De Romeinen gaven de globe de betekenis die hij tot op de dag van vandaag heeft, als symbool van wereldlijke macht en het grondgebied waarover geheerst wordt. ${ }^{13}$ Het kruis op de bol geeft aan dat de vorst zo zal regeren dat hij de bescherming van het kruis verdient, kortom volgens christelijke normen. De scepter symboliseert het absoluut koningschap. $\mathrm{Al}$ in het oude Egypte en Mesopotamië droegen belangrijke personen regelmatig een staf als teken van autoriteit. ${ }^{14}$ Tot diep in de middeleeuwen was de scepter een relatief eenvoudig attribuut, meestal vervaardigd uit verguld koper of verguld zilver. Het rijkszwaard kent zijn oorsprong bij de Germanen. Wanneer Germaanse stammen overblijfselen van het Romeinse rijk in beslag namen werd hun leider gehuldigd. Hij droeg een helm als ceremonieel hoofddeksel en tijdens de plechtigheid hield hij zijn zwaard vast, als symbool van zijn macht en militaire autoriteit.

\section{De kroon van 1815}

Deze Grondwet zal, nevens de Koninklijke kroon, den scepter en den rijks-appel, op eene kredenstafel, in de nabijheid van den troon, gereed liggen, en toevertrouwd blijven aan het opzigt van de officieren van 's Konings huis, welke niet mede in den trein rijden. ${ }^{15}$

Dit is punt 25 uit het draaiboek van de dag van de inhuldigingsplechtigheid in Brussel, opgesteld door de kamerheer ceremoniemeester A.C. baron Snouckaert van Schauburg - en tevens de enige keer dat het woord 'kroon' valt in één van de vele officiële documenten over de inhuldiging 1815. In plaats van in de Nieuwe Kerk in Amsterdam, waar Willem I anderhalf jaar eerder was ingehuldigd tot soeverein vorst, vond de plechtigheid ditmaal plaats in de Brusselse openlucht. Het huldigen van een 


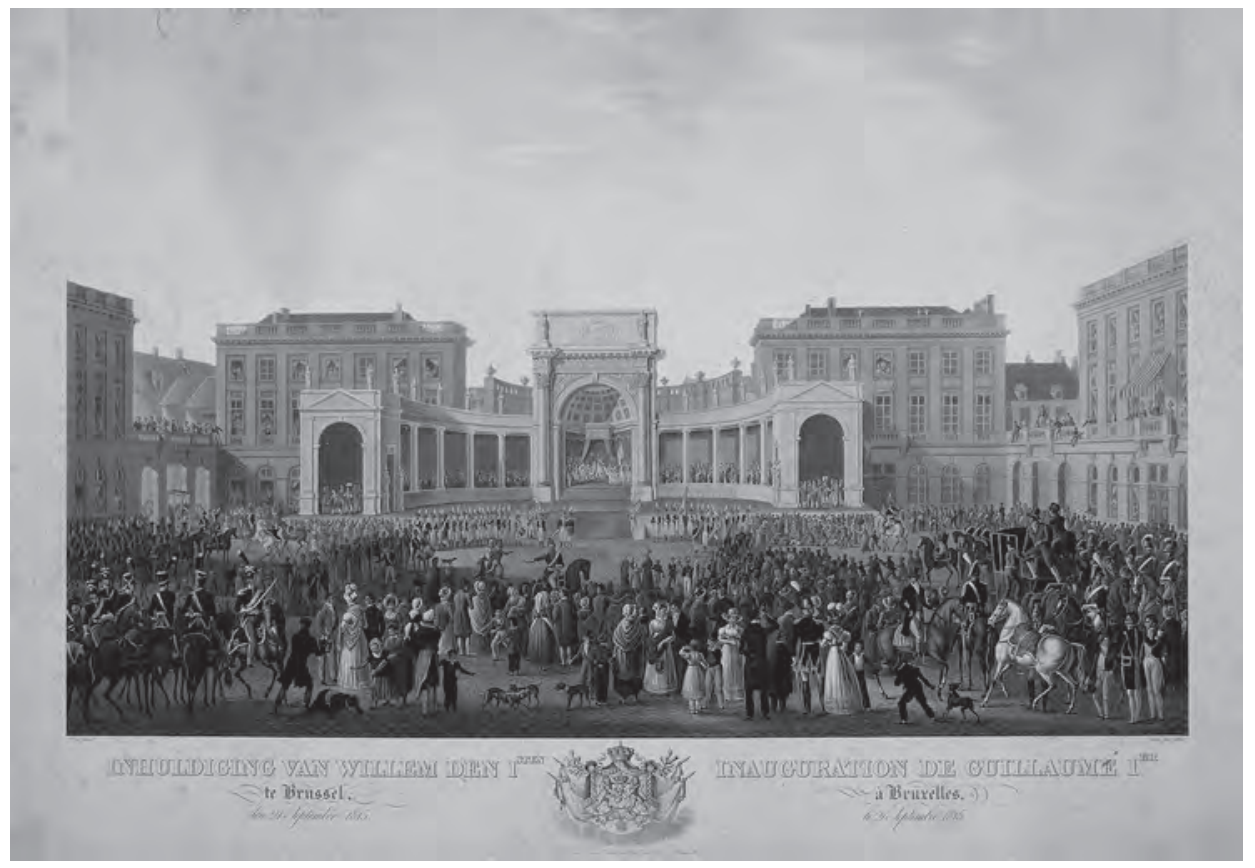

Eedaflegging van koning Willem I, Brussel 21 september 1815 (aquatint, Johann Nepomuk Gibèle, naar een schilderij van Sébastien Leroy, druk 1825-1826; Koninklijke Verzamelingen, Den Haag)

vorst in de openlucht is naar oud Brabants gebruik en aangezien ook de Zuidelijke Nederlanden nu onderdeel van het koninkrijk waren, werden er verschillende aanpassingen in de plechtigheid doorgevoerd. Het eerste gedeelte van de ceremonie vond plaats in het stadhuis, waar de grondwet in het geheel werd voorgelezen door een secretaris van staat. Tijdens dit onderdeel van het programma was er nog geen rol weggelegd voor de kroon. Na deze plechtigheid verplaatste het gezelschap zich naar de Koningsplaats, waar een inhuldigingstheater was gebouwd. De rijksstandaard en het rijkszwaard werden in deze stoet meegedragen. Het tijdelijke houten theater bestond uit een triomfboog met aan weerszijden een zuilengalerij en allegorische versieringen, waaronder achttien vrouwfiguren die de koninklijke deugden uitbeeldden, zoals bedachtzaamheid en waakzaamheid. ${ }^{16}$ Centraal in het theater stond de troon met rechts daarvan een credenstafel met daarop de grondwet, kroon, scepter en rijksappel. ${ }^{17}$ Tijdens deze tweede publieke ceremonie legde de koning een eed af op de grond- 
wet. Tot slot riepen de koningen van wapenen 'Leve de koning!' en 'Vive le Roi', werd het Wilhelmus ten gehore gebracht en er werden 101 saluutschoten afgevuurd. ${ }^{18}$

De plechtigheid van 21 september 1815 was een inhuldiging en géén kroning. Bij een kroning - het woord zegt het al - wordt een kroon op het hoofd van een vorst geplaatst om daarmee zijn macht kenbaar te maken. Dit is een sacrale wijding en dient daarom uitgevoerd te worden door een zeer hoge religieuze autoriteit. Dit lag in Nederland, zeker in die tijd vanwege de samensmelting met het katholieke België, niet bepaald gemakkelijk, want wie zou de kroning dan uit moeten voeren: een hoge vertegenwoordiger van het protestante geloof of toch de paus? Daarnaast lag de plechtigheid sowieso al gevoelig, aangezien Willem I toch vrijwel uit het niets ook koning was geworden van de Zuidelijke Nederlanden, een gebied dat er zelf niet om had gevraagd. De gevoeligheidskwestie bij te veel ceremonieel, alsmede de vraag wie de plechtigheid dan zou moeten voltrekken, deed ertoe besluiten over te gaan tot het huldigen in plaats van kronen van de vorst. Uit correspondentie tussen Willem I en zijn moeder valt op te maken dat de koning graag alsnog, op een later en rustiger moment, gekroond had willen worden. ${ }^{19}$ Gaandeweg zal hij toch op andere gedachten zijn gebracht, want een kroning van een lid van de familie van Oranje-Nassau heeft met uitzondering van die van Koning-Stadhouder Willem III - nooit plaats gevonden.

Tot voor kort was niet bekend door wie de kroon van 1815 was vervaardigd. Verschillende auteurs hebben geschreven dat de kroon werd geleverd door het Amsterdamse juweliershuis Ciovino en de gebroeders Truffino. Deze in 1803 gevestigde zaak was erg succesvol en leverde in haar beginjaren regelmatig sieraden aan Koning Lodewijk Napoleon. Na terugkeer in Nederland werd ook de familie van Oranje-Nassau klant en vanaf 21 augustus 1815 mocht de firma officieel de titel hofjuwelier dragen. ${ }^{20}$ Een schriftelijke bron voor de bewering dat de kroon door dit juweliershuis zou zijn vervaardigd, wordt nergens opgevoerd en heb ik zelf ook nooit kunnen vinden. Wel is er een factuur bewaard gebleven (d.d. 5 oktober 1815) voor een levering van juwelen door Ciovino en Truffino aan de betaalmeester van 's konings huis à fl. 170.000. ${ }^{21}$ Persoonlijk kon ik mij niet goed vinden in deze toeschrijving, aangezien het juweliershuis juist veel aanzien genoot vanwege de hoge kwaliteit van haar producten en de kroon van 1815 niet ditzelfde niveau heeft.

Een tweede theorie over de herkomst van de kroon was dat de kroon niet zou zijn vervaardigd ten behoeve van de inhuldiging van 1815, maar dat er een bestaande, mogelijk eerder tijdens een begrafenis gebruikte, kroon zou zijn hergebruikt. ${ }^{22}$ Toen ik in Staatssecretarie en van het Kabinet des Konings, met de daarbij gedeponeerde archieven, 1813-1840, 2.02.01, inv.nr. 5065, 908.

KV, inv.nr. E18a K 3. Nederlandsche Staatscourant, nr. 223 (20 september 1815). E. Elzenga, 'De functie van de Nederlandse regalia', Nederlandse Leeuw 97 (1980), 113. Brus, De juwelen, 147; Nationaal Archief, Den Haag (NA), inventaris van de archieven van de Algemene NA, 2.02.01, inv.nr. 5065, 1063. Brus, De juwelen, 131. 
2008 , in het kader van een scriptie, onderzoek deed naar dit object behoorden deze beide herkomsttheorieën nog tot de mogelijkheden. Mijn scriptie De kroon van 1815 sloot ik af met de wens deze detective ooit nog op te lossen. ${ }^{23}$ Dat gebeurde, geheel onverwachts, een kleine vier jaar geleden op Twitter. De kroon van 1815 werd uitgeleend aan de tentoonstelling Crowned in Museum Rijswijk. Voor dat doel schreef ik - inmiddels conservator bij de Koninklijke Verzamelingen - een korte tekst over het object voor onze website. Vrijwel direct na publicatie twitterde Trudie Rosa de Carvalho, destijds conservator bij Nationaal Museum Paleis Het Loo, dat het haar opviel dat de vervaardiger in onze omschrijving ontbrak, terwijl het toch bekend was dat dit Pierre Meijer moest zijn. Wat bleek: Rosa de Carvalho was tijdens een eigen ander onderzoek bij toeval op dé rekening gestuit, met het antwoord op de voor mij in 2008 zo belangrijke vraag.

Uit deze rekening valt op te maken dat de Brusselse vergulder Pierre Meijer op 20 september 1815 'pour l'inauguration de Sa Majesté le Roi des Pays Bas' een vergulde kroon, scepter en rijksappel leverde. ${ }^{24}$ De kroon van 1815 is in vormentaal zeer vergelijkbaar met de heraldische kroon op het koninklijke wapen van 1815 en is gemaakt van verguld koper. De onderste brede band is bezet met verschillende vrij grote glasstenen, welke zijn gezet op zilverfolie om extra schittering te bewerkstelligen. Op de band zijn een achttal gestileerde (aardbei)bladeren - ook wel fleurons geheten - bevestigd met op elk blad centraal een blauw steentje. Vanuit deze bladeren ontspringen acht met een parelmotief versierde brede beugels, die met een kromming naar binnen lopen en in het midden getopt worden met een rijksappel. De kroon is van binnen bekleed met rood fluweel. De doorsnede van de kroon is dermate omvangrijk, dat het duidelijk is dat deze niet is gemaakt om op een hoofd te dragen.

Er zaten slechts twintig dagen tussen de dag waarop Willem I zijn handtekening plaatste onder het document waarin staat dat zijn inhuldiging zou plaats gaan vinden en de daadwerkelijke inhuldiging op 21 september $1815 .{ }^{25}$ Dit roept de vraag op of de regalia in deze twintig dagen vervaardigd zijn of dat de opdracht voor de vervaardiging ervan wellicht al eerder is gegeven, het ging immers om een wezenlijk staatssymbool. Bijna alle auteurs die de kroon hebben besproken, spreken over een haastklus. Vermoedelijk baseren zij deze veronderstelling op de tijdspanne van twintig dagen. Feit is dat de rekening dateert van één dag voor de inhuldiging.

De organisatie van grote ceremoniën, alsmede de opdracht tot het doen vervaardigen van de regalia en het koninklijk gewaad werden neergelegd bij de Hoge Raad van Adel. ${ }^{26}$ Deze instantie, die alle zaken omtrent de adel officieel regelt en archiveert, werd slechts enkele maanden na de terugkeer van Willem I in Nederland in het leven

L. Smeets, De kroon van 1815. Masterscriptie Algemene Cultuur Wetenschappen (Utrecht, 2008). KV, Eo8-XIV-08, jan cap IX nr.1. In het in 2013 gepubliceerde De Inhuldigingen van Willem I tot Beatrix schrijft E. Elzenga op pagina 160 de kroon ook toe aan P. Meijer, waar hij eerder in het in 1990 gepubliceerde Theater van Staat nog Ciovino en de gebroeders Truffino als maker aanwees.

Brus, De juwelen, 130.

Elzenga, Theater van staat, 8. 




Kroon van Willem I (verguld

koper, glas en textiel, Pierre

Meijer, 1815; Koninklijke Ver-

zamelingen, Den Haag)

geroepen, op 24 juni $1814 \cdot{ }^{27}$ De persoon die verantwoordelijk was voor de uitvoering van deze opdracht was Willem Anne baron van Spaen la Lecq, vanaf 1814 voorzitter van de Hoge Raad van Adel. In deze hoedanigheid schreef hij op 20 september 1815, slechts één dag voor de inhuldigingsplechtigheid, een brief aan de koning met daarin de stand van zaken. In deze brief is ook één paragraaf gewijd aan de regalia:

Deze middag zal ik ontvangen de kroon, scepter en kloot, zo als ook het Rijks standaard. Het zij nog geoorloofd deze kleinoden, dezen avond, aan uwe majesteit te vertonen, waarna ik dezelve incognito ten huize van den heer graaf van Thiennes zal brengen. Ondertekend: Spaen La Lecq, Brussel 20 september $1815 .{ }^{28}$

Uit deze brief blijkt dus dat de regalia slechts één dag voor de ceremonie aan de heer van Spaen la Lecq werden overhandigd, hetgeen correspondeert met de datum van de factuur. Daarnaast kan uit de brief worden opgemaakt dat de koning de attributen pas de avond voor zijn inhuldiging voor het eerst onder ogen kreeg.

\section{De functie van de kroon}

De rol van de kroon was op 21 september 1815 vrij gering, aangezien deze alleen lag op de credenstafel in de nabijheid van de troon en er verder geen handelingen mee werden verricht. Daarnaast wordt zij ook niet vermeld in draaiboeken, beschrijvingen van de dag of in officiële mededelingen, zoals proclamaties. Uit dit alles valt te 
concluderen dat de rol van de kroon in 1815 daadwerkelijk vrij klein was en dat deze echt enkel gezien moet worden als een symbool voor de Nederlandse staat. Of zoals Elzenga schrijft in zijn Theater van Staat: 'een voorwerp van louter heraldische aard, een symbool van de rang van land en vorst.'29 Ook de goedkope uitvoering van de regalia ondersteunt deze gedachte. Een symbool hoeft immers niet gemaakt te worden van de meest kostbare materialen, maar moet vooral iets verbeelden, iets visualiseren. Door een grote kroon naast een troon in een allegorisch versierd theater te plaatsen, konden toeschouwers ook van ver zien dat het om een bijzondere gebeurtenis ging en dat de persoon die centraal stond niet zomaar iemand was, maar een koning.

Met de terugkeer van Willem I is er specifiek gekozen om de traditie van vóór de Franse Revolutie niet opnieuw op te pakken. Men koos voor een nieuw begin met aan het hoofd een oude familie. Het meest kenmerkend voor deze beslissing is het gegeven dat Willem Frederik vanaf dat moment door het leven ging als Koning Willem I en niet als Willem VI. Nederland was, afgezien van de korte periode onder Lodewijk Napoleon, niet eerder een koninkrijk geweest en ook de grenzen lagen anders. Deze nieuwe situatie vroeg om keuzes op het gebied van titulatuur, staatsinrichting en de symbolentaal. In 1815 werd er een traditie geboren, een traditie die de schijn had al eeuwen te bestaan, hetgeen natuurlijk ook voor een deel klopt.

De ceremonie van 1815 en de nieuwe regalia zijn een schoolvoorbeeld van de door Eric Hobsbawm en Terence Ranger geponeerde theorie van de 'invention of tradition' ${ }^{30} \mathrm{Zij}$ bespreken drie verschillende soorten 'invented traditions', waarvan er twee naadloos aansluiten bij de situatie van Nederland in $1815 .^{31}$ Het eerste type is een nieuwe traditie die de cohesie van een groep verbeeldt en deze zo probeert te bevorderen. Dit geldt zeker voor de inhuldigingsceremonie van 1815; er werd immers voor een ceremonie gekozen die het best paste bij de nieuwe situatie. De ceremonie vond plaats in de openlucht en de bevolking werd er op diverse manieren bij betrokken: via omroepers, muziek, het verspreiden van herdenkingsmunten en het bezoek van de koning aan diverse plaatsen. Het dusdanig betrekken van het volk bij de festiviteiten evenals de samenstelling van het programma - waarbij er gebruiken van de Noordelijke en van de Zuidelijke Nederlanden aan bod kwamen - waren er zodoende op gericht het een memorabele dag voor en van iedereen te maken.

Een tweede door Hobsbawm en Ranger onderscheiden punt is de gecreëerde traditie, die zorgt voor de legitimatie van instituties, status of macht. Ook dit punt is van toepassing op de plechtigheid van 1815 , waarbij met name de attributen - waaronder ook de ook regalia - letterlijk symbool stonden voor de macht van de koning en het instituut: de constitutionele monarchie, het nieuwe Nederland.

Elzenga, Theater van staat, 8.

30 E. Hobsbawm, The Invention of Tradition (Cambridge, 2007), 4.

31 Ibidem, 9. 
Niet alleen Nederland, maar heel Europa kreeg in het eerste kwartaal van de negentiende eeuw nieuwe landsgrenzen. De inventie van de hier beschreven traditie valt in een heel cluster van nationale en internationale vernieuwingen. Zowel de inhuldigingsceremonie als de regalia kennen een sterke historische verwijzing, en wel naar de tradities op het Nederlands grondgebied van vóór de Fransen en naar de stadhouderlijke familie. Door verschillende oude tradities en rituelen te incorporeren en in een actueel jasje te steken, leek het nieuwe niet bedacht maar vanzelfsprekend.

\section{Een nieuwe kroon voor de Inhuldiging van koning Willem II}

Voor de inhuldiging van Koning Willem II op 28 november 1840 werd door de firma Bonebakker in Amsterdam een nieuwe kroon vervaardigd. Deze kroon, die sindsdien voor de verschillende inhuldigingen is gebruikt, is vergeleken met de kroon van Willem I iets rijker uitgevoerd, maar verwijst qua model sterk naar zijn voorganger. Er worden verschillende argumenten gegeven voor de introductie van deze nieuwe kroon. Eén ervan is de goedkope uitvoering van de kroon van Willem I, hetgeen echter niet geheel logisch is aangezien de kroon van Willem II nog altijd met glasstenen bezet is en het materiaal ook nog altijd niet heel kostbaar. Deze tweede kroon is namelijk gemaakt van verguld zilver in plaats van koper en kostte slechts 1.400 gulden, inclusief het maakloon van de smid..$^{22}$ Het lijkt dus veel logischer de aanleiding van deze vervanging wederom te zoeken in de symboliek. Willem II nam zijn vaders troon over vlak na de afscheiding van de Zuidelijke Nederlanden, een afscheiding die voor zijn vader haast onaanvaardbaar was. De kroon die was gebruikt tijdens de ceremonie van 1815 in Brussel, was niet alleen het symbool van het rijk onder zijn vader maar ook van een verenigd Nederland en een in Brussel voltrokken ceremonie. Alles werd anders: de plechtigheid vond dit keer niet plaats in de open lucht, maar in de Nieuwe Kerk in Amsterdam. Zodoende lijkt het logisch dat ook de regalia van 1815 eraan moesten geloven. De nieuwe kroon werd iets eleganter, de rijksappel wat verfijnder en in plaats van een parelmotief op de beugels kwamen er imitatieparels. Daarmee beeldt onze huidige kroon nog altijd datgene uit wat de kroon van Willem I ook deed: een lange traditie van leiderschap. De kroon draagt echter niet de 'smet' van de afscheiding van België: kortom een frisse start met een frisse kroon.

\section{Een kroon van hout}

Dat een kroon daadwerkelijk symbool staat voor het koningschap, wordt naar mijn idee mooi geïllustreerd door de - al dan niet bewust - foute beschrijvingen van de kronen van 1815 en 1840 die op verschillende momenten hebben gecirculeerd. Met name het materiaal van de kronen is illustratief geweest in negatieve, dan wel positieve ver- 


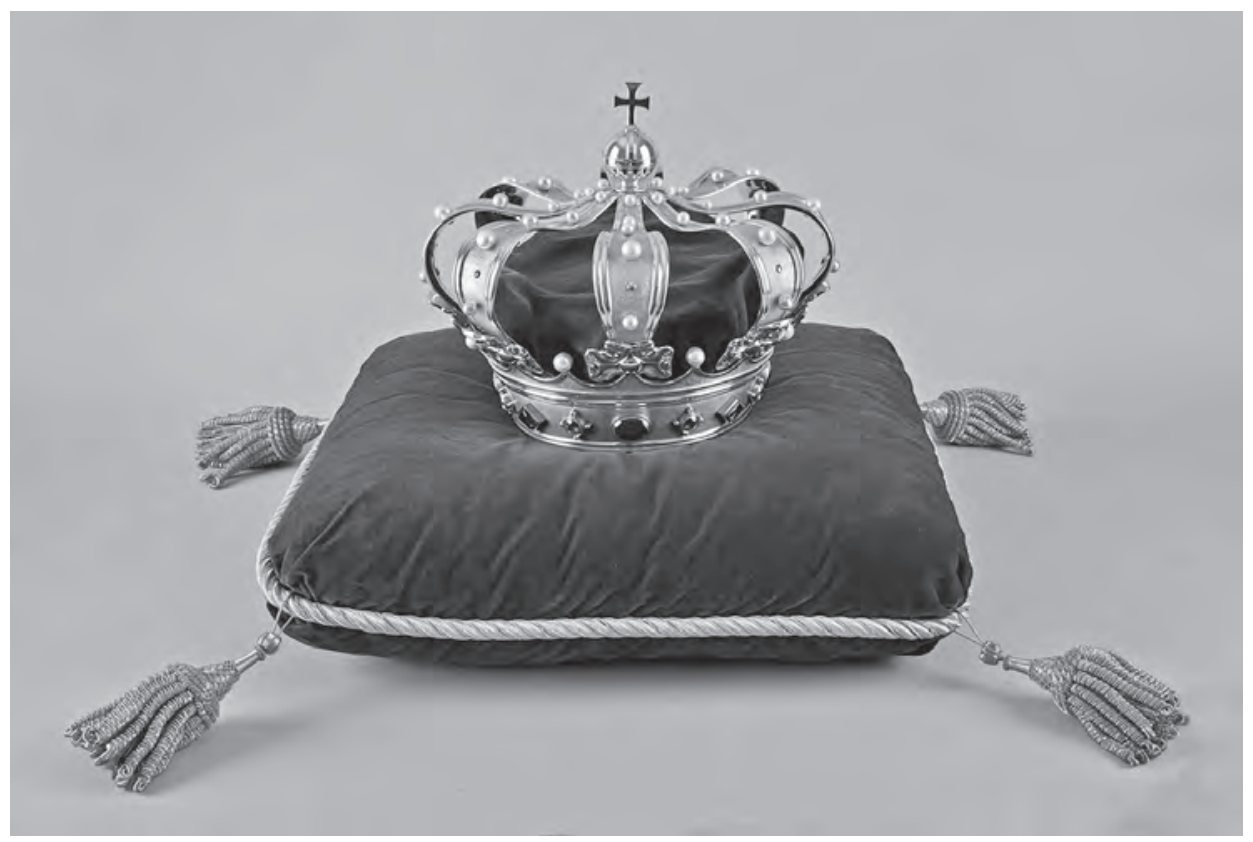

Kroon van Willem II (verguld zilver, glas en textiel, firma Bonebakker, Amsterdam, 1840; Koninklijke Verzamelingen, Den Haag)

halen over het koningshuis. Rondom de afscheiding van België werd er aan Belgische zijde uiteraard negatief geschreven over Willem I en ook zijn kroon moest het ontgelden. Zo schreef Henri de Mérode in 1830: 'De koning droeg op het hoofd een kroon van verguld hout, waarvan de edelstenen van gekleurd glas waren.' ${ }^{33}$ Nadien is de kroon van koning Willem I nog vele malen als van hout omschreven. Mozes Heiman Gans reageerde hierop in zijn Juwelen en Mensen: 'Natuurlijk was dit verhaal niet waar. De verguld zilveren kroon, die nog altijd bewaard wordt, was weliswaar zeer eenvoudig van uitvoering, maar juist die eenvoud is typerend voor Willem I, de "koning-koopman".34

Waar over de kroon van 1815 - sinds de Belgische opstand - meermaals minzaam werd geschreven, is de kroon van 1840 in verschillende verhalen juist opgewaardeerd. Dit is opmerkelijk aangezien er over het materiaal en de maker van deze kroon nooit onduidelijkheden zijn geweest. Het lijkt wel alsof koningsgezinden zich simpelweg niet konden voorstellen dat een kroon van het staatshoofd van iets anders dan van de meest kostbare materialen zou zijn gemaakt. Al vlak na zijn verschijnen werd 
de kroon door Joannes Jacobus Franciscus Wap beschreven in een gedenkboek over de inhuldiging en feesttochten van Willem II:

De kroon, een edel pronkwerkstuk van de Heeren Bonebakker en Zonen, te Amsterdam, is volgender wijze zamengesteld. Eene rood fluweelen toque dient, om de kroon rond het hoofd te doen passen; deze toque is omvat door een gouden band, die met edelstenen van allerlei vonkelende kleur bezet is, als met safiren, smaragden en topazen. ${ }^{35}$

Decennia later schreef zelfs de Rijksvoorlichtingsdienst nog iets vergelijkbaars rond de inhuldiging van koningin Juliana op 6 september 1948:

Vier grote ovaalvormige robijnen, vier langwerpige vierkant gezette saffieren en acht meer kleine in ronde vorm gevatte smaragden en elk dier bandeaux is versierd met een rij van acht paarlen van verschillende grootte. ${ }^{36}$

146 Mogelijk hangen de foutieve omschrijvingen ook samen met de waardering van de figuren Willem I en Willem II. Van de eerste koning is bekend dat hij hechtte aan ceremonieel, als dat maar niet te overdadig of te duur was. ${ }^{37}$ Van Willem II is juist bekend dat hij overdaad best kon waarderen. Zijn - kritische - schoondochter Sophie omschreef hem op de dag van zijn inhuldiging als volgt: 'Gekleed in een soort geborduurde tuniek, een kozakken pet met diamanten op zijn hoofd en de koninklijke mantel over zijn schouders (..). ${ }^{38}$ Omdat een kroon zo'n met betekenis geladen object is, lijkt het moeilijk om de Nederlandse inhuldigingskronen te zien voor wat ze zijn: symbolische objecten door hun vorm, waarbij het materiaal net zo goed hout had kunnen zijn, zonder ook maar enig afbreuk te doen aan de betekenis en kracht.

Laura Smeets (1982) studeerde Algemene Cultuurwetenschappen aan de Universiteit van Amsterdam en studeerde in 2008 af op een onderzoek naar de kroon van Koning Willem I. Twee jaar later voltooide zij aan diezelfde universiteit de master Museumstudies met een onderzoek naar de verzameling 'door kunst gemaakte zeldzaamheden' van stadhouder Willem V. Ze schreef tentoonstellingsconcepten in opdracht van diverse musea en deed herkomstonderzoek in opdracht van Nationaal Museum Paleis Het Loo. Sinds enkele jaren werkt zij als conservator bij de Koninklijke Verzamelingen, waar zij zich vooral richt op de historische objecten en kunstnijverheid in de collectie.

Koninklijke Verzamelingen, Postbus 30412, 2500 GK Den Haag - l.smeets@dkh.nl dam, 1842), 18.

36 Brus, Kronen, 33.

37 Koch, Koning Willem I, 291.

38 J. van Zanten, Koning Willem I/ (1792-1849) (Amsterdam, 2013), 375. 
Valbijl of vangnet? Natuurmonumenten, de adel en de verwerving van landgoederen en buitenplaatsen, 1905-1980

Class, gender and national identity. Music-making in eighteenth-century Dutch noble homes

Joris van Son

Insignia Summorum Principum. Using symbols of power in pursuit of higher rank and status by German prince-electors and Polish-Lithuanian princes Jakub Rogulski

\section{Dossier Adellijke Vrouwen}

'Defending the castle like a man': on belligerent medieval ladies Elizabeth den Hartog

Belle van Zuylen: schrijfster van adel, over de adel. Haar correspondentie digitaal beschikbaar

Suzan van Dijk

Een ruk naar Brits. De internationale politiek van Anna van Hannover, 1756-1757 Simone Nieuwenbroek 